\title{
UNDERSTANDING AND TREATING NEUROPATHIC PAIN
}

Received August 14, 2012.

Maladaptive neuropathic pain results from injury or disease of the nervous system. It is typically chronic and frequently intractable. Standard analgesics, such as opioids, are of little use, while the gabapentinoids, pregabalin and gabapentin, are not universally effective. In peripherally generated neuropathic pain, an initial inflammatory response releases a variety of mediators, including cytokines and prostaglandins that alter ion channel expression in primary afferent neurons. This initiates ectopic activity in sensory nerves and results in the release of ATP and a second group of mediators from primary afferent terminals. The level of spinal microglial activation is altered such that microglia releases a third set of mediators, notably brain-derived neurotrophic factor (BDNF), in the spinal dorsal horn. Through various mechanisms, BDNF increases excitatory synaptic transmission whilst decreasing inhibitory transmission. The resulting "central sensitization" contributes to the hyperalgesia, causalgia, and allodynia that are associated with neuropathic pain. It is suggested that targeting ion channels in the sensory nerves and excitatory transmission in the dorsal horn may lead to urgently needed new treatments for neuropathic pain. It is also suggested that the effectiveness of gabapentinoids may be increased by combining these agents with the TRPV1 agonist capsaicin.

Keywords: peripheral neuropathy, dorsal root ganglion, dorsal horn, cytokines, gabapentin.

\section{INTRODUCTION}

Pain is an unpleasant, yet vital, physiological process that signals on actual or potential tissue damage. By so doing, it ensures the survival of the species. In contrast, injury to the somatosensory system can produce "neuropathic" pain that lasts for months or years after any injury has healed $[1,2]$. This maladaptive "disease of pain" has a $1.5-3 \%$ prevalence within the general population $[3,4]$ and imposes a significant financial burden on health-care systems. Neuropathic pain can be associated with diabetic, postherpetic, or HIV-related neuropathies, with fibromyalgia and osteoarthritis, and with traumatic nerve, spinal cord, or brain injuries (including stroke). It is characterized by allodynia (generation of a painful sensation in response to an innocuous stimulus), hyperalgesia (a heightened response to a noxious stimulus), and causalgia (an ongoing burning pain experienced by many neuropathic pain patients), as well as shooting or

\footnotetext{
${ }^{1}$ Centre for Neuroscience and Department of Pharmacology, University of Alberta, Edmonton, Canada.

Correspondence should be addressed to P. A. Smith

(e-mail: peter.a.smith@ualberta.ca).
}

"electric shock-like" spontaneous pain. It is difficult to treat as it is characteristically resistant to the action of opioids and other "standard" analgesics. "Antiallodynic" drugs, such as canabinoids, amitriptyline, gabapentinoids, and other anticonvulsants, are effective only in about $30 \%$ of patients [4-7]. There is a clear need therefore for improved understanding of the aberrations of sensory processing that underlie the emergence and persistence of neuropathic pain. This review will outline the current status of our understanding of the etiology of neuropathic pain, as might result from peripheral nerve trauma or diseaseassociated peripheral neuropathy. We will seek to identify aspects of the pathophysiological process that may represent targets for therapeutic intervention.

\section{GENERAL MECHANISMS OF NEUROPATHIC PAIN: THE CCI MODEL}

Peripheral nerve damage, such as that generated by chronic constriction injury (CCI) of the sciatic nerve, induces pain-related behaviors in rodents that are ethically and scientifically accepted as a model 
for many forms of human neuropathic pain. Sevenor more day-long CCI promotes release of proinflammatory cytokines, growth factors, and other mediators from damaged and inflamed tissue at the site of the injury [2, 7, 10,11] (Fig. 1). These factors act directly on first-order primary afferent neurons to produce an enduring increase in their excitability [1214]. This promotes release of a second set of mediators (cytokines, chemokines, neuropeptides, ATP, and growth factors) from glutamatergic primary afferent terminals in the spinal dorsal horn. These alter the state of activation of spinal microglial cells $[15,16]$, which, in turn, release yet another set of mediators, including brain-derived neurotrophic factor (BDNF). This set promotes a slowly developing increase in the excitability of second-order neurons in the dorsal horn of the spinal cord [16-19]. This change, which develops progressively during CCI, is known as central sensitization [20-24]. Whereas alterations in spinal microglial signaling trigger pain onset, enduring activation of astrocytes is thought to be responsible for the maintenance of central sensitization $[7,17$, $25,26]$. The persistence of neuropathic pain also involves enduring changes in thalamic and cortical physiology [27, 28], changes in descending inhibition from the rostral ventromedial medulla [7, 29-33], and long-term sensitization of peripheral nociceptors $[7$, $33,34]$. Although neuropathic pain can result from a variety of insults to peripheral nerves, including diabetic or HIV-AIDS neuropathy [35, 36], axotomy $[12,13,37]$, nerve crush [38], or compression injury [39], the appearance of ectopic action potentials and spontaneous activity in primary afferent fibres seems to be the initial trigger that initiates central sensitization in many, if not all, types of peripherally generated neuropathic pain $[13,24,39-46]$, including that associated with herpes zoster [47] and HIV infection. More importantly, these changes in sensory nerve activity are maintained as long as the pain persists [13]. Persistent ectopic afferent activity is thought to provide increased excitatory drive to neurons in the already sensitized dorsal horn [48, 49].

\section{TARGETS FOR THERAPEUTIC INTERVENTION}

As was mentioned above, neuropathic pain is relatively resistant to the action of opioids. This likely reflects down-regulation of $\mu$-opioid receptors at a variety of points in nociceptive transmission pathways [50, 51]. Figure 2 illustrates high voltage-activated (HVA) $\mathrm{Ca}^{2+}$ channel currents $\left(I_{\mathrm{Ca}}\right)$ recorded from small neurons of the rat dorsal root ganglia (DRGs). In animals subjected to axotomy-induced nerve injury, the ability of the $\mu$-opioid DAMGO to reduce $\mathrm{N}$-type $I_{\mathrm{Ca}}$ is decreased [51]. In control animals, DAMGO reduced this current by $34.8 \pm 2.3 \%(n=15)$ compared to a

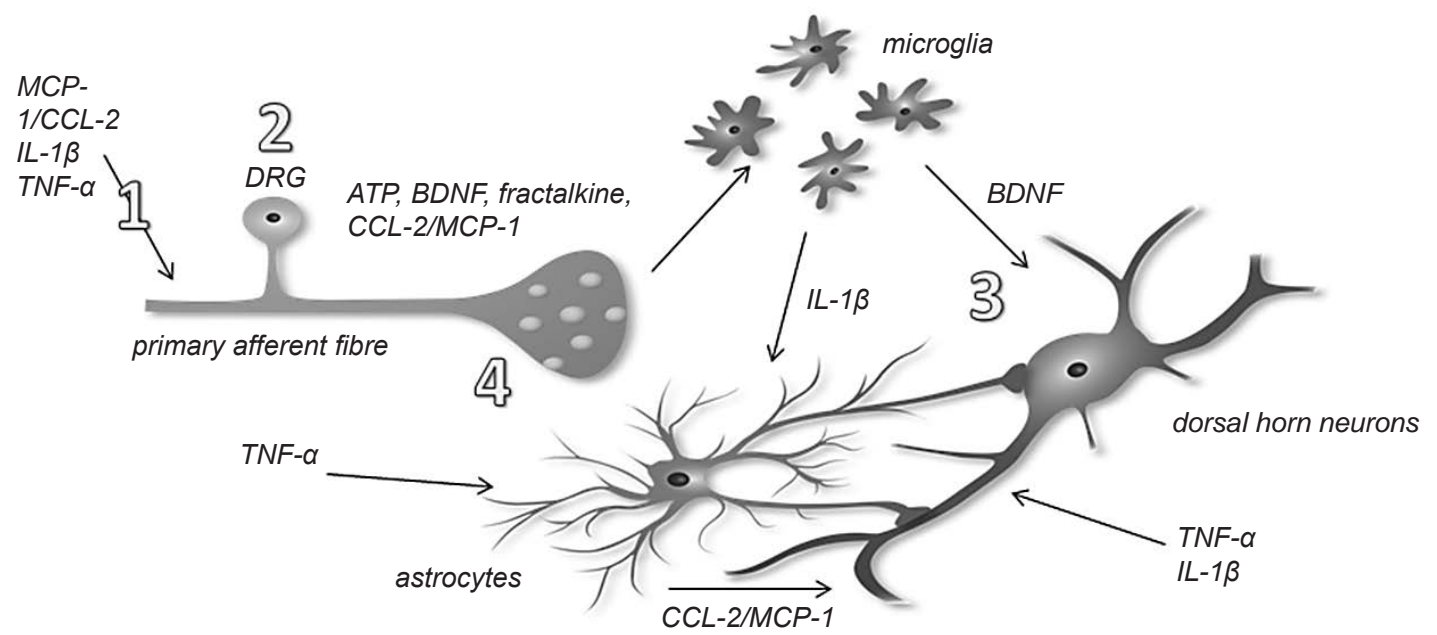

F i g. 1. Scheme to show interactions between primary afferents, dorsal horn neurons, microglia, and astrocytes in the context of chronic pain (modified from Biggs et al. [77] and reproduced here under a Creative Commons Attribution License; http://creativecommons.org/ licenses/by/2.0).

Р и с. 1. Схема, яка ілюструє взаємодію первинних аферентів, нейронів дорсального рога, мікроглії та астроцитів у разі хронічного болю. 

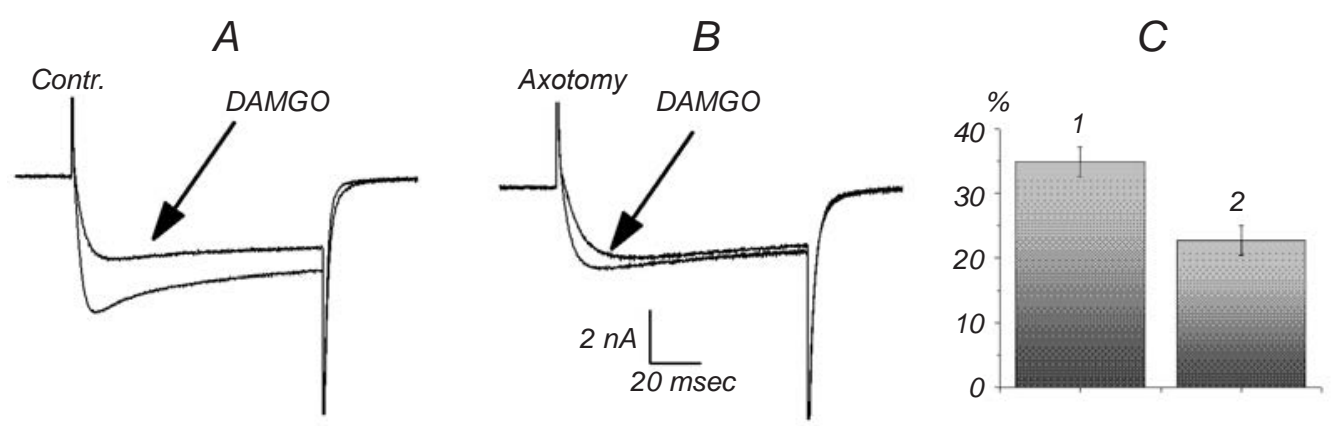

F i g. 2. Ten days of sciatic nerve injury (induced by axotomy) reduces $\mu$-opioid effectiveness in small dorsal root ganglia (DRG) neurons. $\mathrm{A}$ and B) Examples of HVA $\mathrm{Ca}^{2+}$ channel currents recorded in response to voltage steps to $-10 \mathrm{mV}$ from $-90 \mathrm{mV}$. Ba ${ }^{2+}$ was used as the charge carrier (for further details, see Abdulla and Smith [51]). The $\mu$-opioid agonist DAMGO (1 mM) produces robust suppression of the current in a control DRG neuron (A), but a much weaker effect on a small DRG neuron derived from an animal 10 days after sciatic nerve section (axotomy, B). C) Summary of the effects of a $\mu$-opioid on $\mathrm{Ca}^{2+}$ channel currents in small L4-L6 DRG neurons from control animals and those 10 days after sciatic nerve axotomy. Under control conditions (1), $1 \mathrm{mM}$ DAMGO reduced the current by $34.8 \pm 2.3 \%(n=15)$ compared to $22.6 \pm 2.3 \%(n=12)$ depression in nerve-injured (axotomized, 2$)$ animals $(P<0.03)$. Vertical scale) Suppression of HVA $I_{\mathrm{Ca}} \%$.

Р и с. 2. Послаблення дії $\mu$-опіоїду на дрібні нейрони гангліїв дорсальних корінців через 10 днів після ушкодження сідничного нерва (аксотоміі).

$22.6 \pm 2.3 \%(n=12)$ reduction in depression in nerveinjured (axotomized) animals $(P<0.03$, Fig. 2C); an effect is likely attributable to decreased expression of functional opioid receptors.

Non-opioid drugs with established clinical efficacy in neuropathic pain include cannabinoids, gabapentinoids (pregabalin and gabapentin), and noradrenaline/serotonin uptake blockers (amitriptyline and venlafaxine) [5]. The efficacy of drugs is related to etiology of the pain, with HIV-AIDS neuropathy being particularly resistant. As was mentioned, therapeutic management of all types of neuropathic pain combined is effective only in $30 \%$ of the patients. For this reason, new therapeutic approaches are urgently required. We will consider four possible points of intervention in the scheme shown in Fig. 1. These are: (i) blocking the action of inflammatory mediators at the site of injury, (ii) blocking consequences of mediator action at the site of injury, (iii) targeting synaptic transmission in the spinal dorsal horn, and (iv) augmenting the effectiveness of currently available therapies.

Blocking the Action of Inflammatory Mediators at the Site of Injury. Although it has been demonstrated repeatedly that interference with the actions of cytokines or growth factors can delay or prevent the onset of neuropathic pain in animal models [52-54], this may not be relevant to pain management in the clinical situation. Patients experiencing neuropathic pain are typically examined several months after an initial trauma. In the case of pain associated with disease-related neuropathies, it is impossible to determine when pathophysiological changes underlying the pain were actually initiated. Thus, therapies must be directed against chronic changes initiated by inflammatory mediators rather than toward blocking their action per se. This idea is underlined by data shown in Fig. 3. The latter illustrates the time course of changes in the withdrawal threshold for a pressure stimulus in rats subjected to CCI of the sciatic nerve. As the animals develop signs of allodynia and hyperalgesia, the withdrawal threshold drops from an initial value of about $15 \mathrm{~g}$ to $2.41 \pm 0.49 \mathrm{~g}$ $(n=12)$ over a 6 -day-long period but then remains practically constant for further 9 days $(2.98 \pm 0.58 \mathrm{~g}$ at day 15). Open circles on the graph are replotted values from the communication of Nadeau et al. [54] showing relative levels of IL-1 $\beta$ in the rat sciatic nerve after injury. The cytokine concentration peaks after about 7 days and then declines. At the 14th day, the cytokine concentration is starting to revert to control values, yet the reduced withdrawal threshold (indicative of allodynia) persists. Thus, blocking cytokine action (at least IL-1 $\beta$ action) is unlikely to be effective in the clinical situation. It is analogous to "closing the barn door after the horse has bolted." It is also possible that preventing all actions of cytokines may be deleterious, as this may compromise functional recovery of injured nerves [54].

Blocking Consequences of Mediator Action at the Site of Injury. Since, as was mentioned above, 
the appearance of ectopic action potentials and spontaneous spike activity in primary afferent fibres seems to be the initial trigger that initiates central sensitization in many, if not all, types of peripherally generated neuropathic pain $[13,24,39-46]$; ion channels in primary afferent neurons represent an attractive target for therapeutic intervention. It is relevant to mention in this context that several standard therapeutic approaches to treat neuropathic pain [5] are directly or indirectly targeted toward ion channels. For example, gabapentinoids affect $\mathrm{Ca}^{2+}$ channel expression [55-59], and some drugs, such as carbamazepine and ziconotide, target ion channels directly [60].

In the context of the scheme illustrated in Fig. 1, recent work in our laboratory was focused on studying the long-term actions of IL- $1 \beta$ on dissociated DRGdefined medium culture $[14,61,62]$. Since, as is illustrated in Fig. 3, nerve injury causes a peak increase in the IL- $1 \beta$ concentrations after 7-day-long CCI, and this is returning to control values after 14 days [54], we exposed DRG neurons to IL-1 $\beta(100 \mathrm{pM})$ for periods of 5 to 6 days. Recordings were made from large

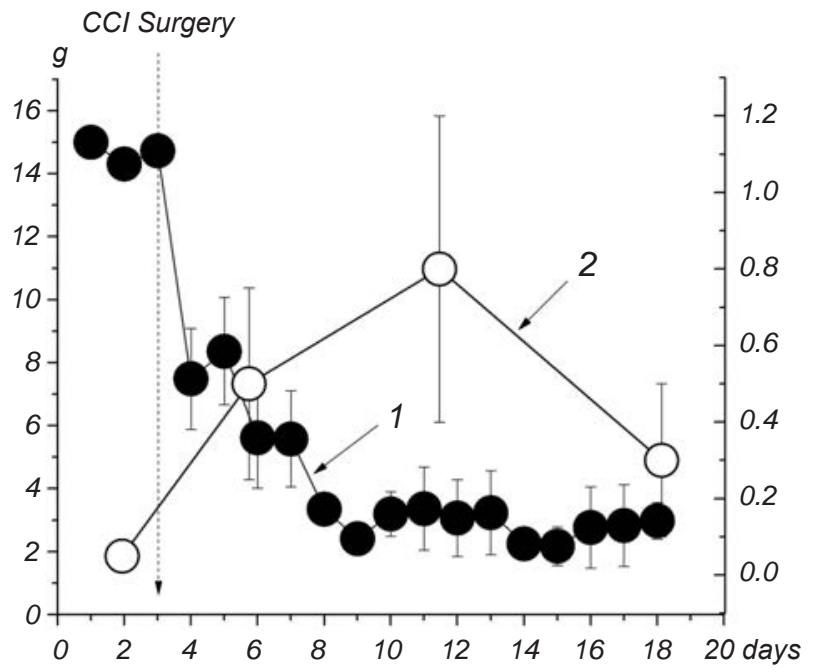

F i g. 3. Comparison of changes in the withdrawal threshold $(1, g)$ and relative levels of IL-1 $\beta$ (2) in the sciatic nerve following chronic constriction injury (CCI) of the rat sciatic nerve. Open circles represent the time course of the effects of relative concentrations of IL-1 $\beta$ replotted from the published data of Nadeau et al. [54]. Filled circles represent the withdrawal thresholds of the operated limb determined with Von Frey filaments (s.e.m. are also shown for results on 12 animals).

Р и с. 3. Порівняння змін порога відсмикування кінцівки (1, ліва шкала, г) і відносного рівня IL-1 $\beta$ (2, права шкала, ум. од.) у сідничному нерві після хронічного передавлювання (CCI, позначено пунктирною лінією) цього нерва. neurons defined by brief sharp action potentials, from medium-sized neurons with somewhat broader spikes, which are believed to be the cell bodies of nociceptive A $\delta$ fibers, and from two categories of small cells with broad spikes (Fig. 4). The latter represent cell bodies of C-fibers, but those binding the plant lectin IB4 are thought to be non-peptidergic, whereas those failing to bind the lectin may be peptidergic and are more likely to be nociceptive. The effects of IL-1 $\beta$ were cell type-specific. Whereas the excitability of medium
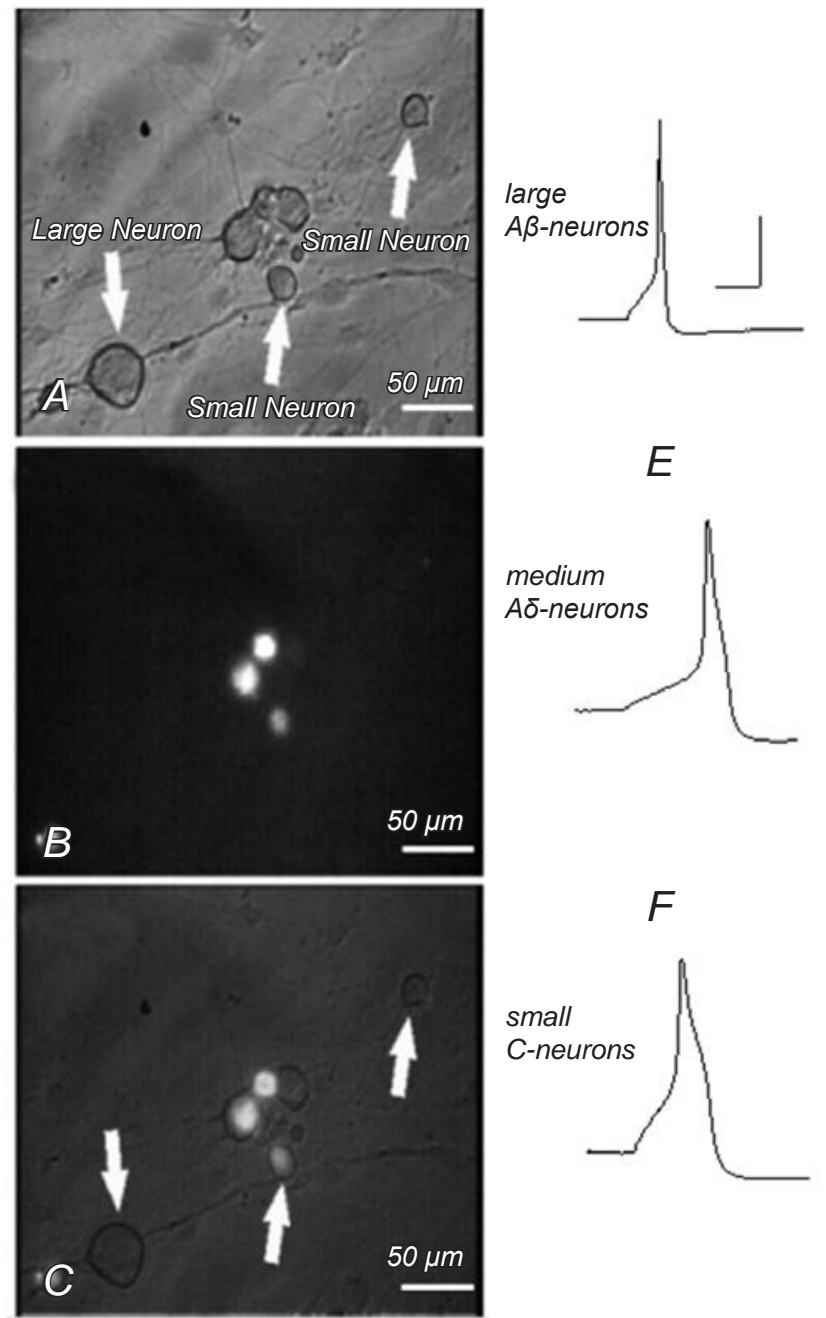

F i g. 4. Illustration of neuron types in the rat dorsal root ganglion (DRG). A) Phase-contrast photomicrograph of cultured DRG neurons to show that large and small neurons can be readily distinguished in such cultures. B and C) After incubation of neurons with fluorescently labeled IB4; some small cells exhibit IB4 binding, whereas others do not (marked with open arrows). D-F) Action potentials recorded from large, medium, and small DRG neurons, respectively.

Р и с. 4. Типи нейронів у дорсальнокорінцевому ганглії щура. 

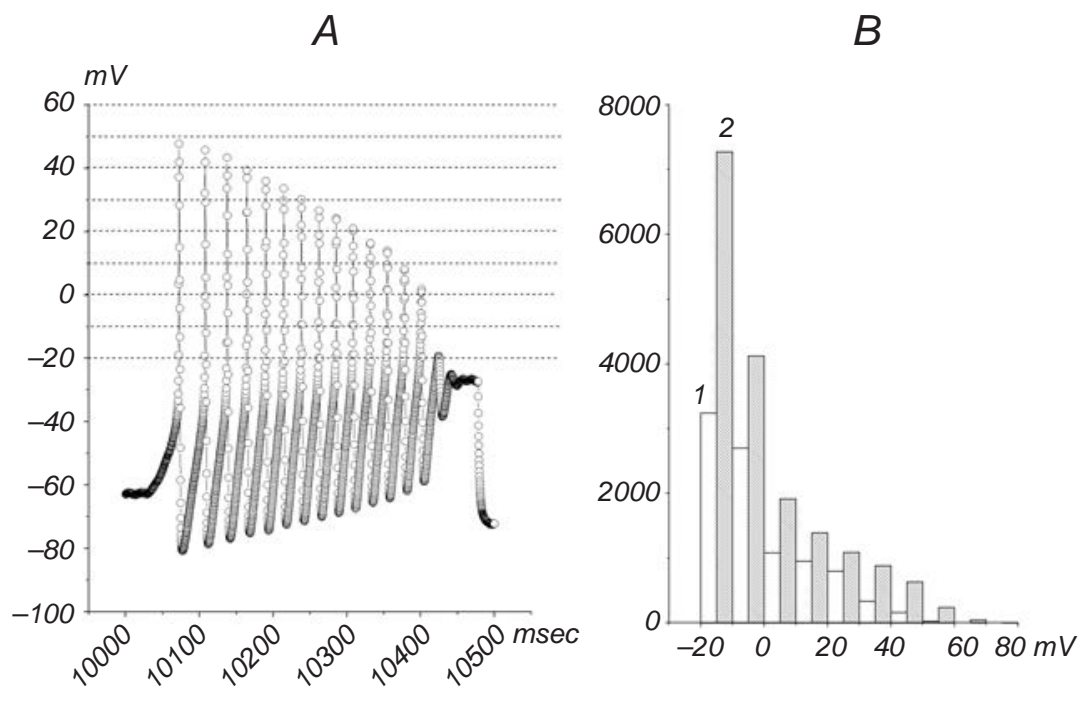

F i g. 5. Use of all-point histograms to illustrate an IL-1 $\beta$-induced increase in the excitability of medium DRG neurons. A) Action potentials (APs) evoked using a standard current-clamp command ( 0 to $2 \mathrm{nA}$ in 500 $\mathrm{msec}$ ). Resting potential was standardized to $-60 \mathrm{mV}$ by steady-state current injection. Digital points describing AP trajectories have been assigned to $10 \mathrm{mV}$ bins starting from $-20 \mathrm{mV}$. Abscissa) Time, msec; ordinate) voltage, mV. B) Resultant histograms using all digital points collected from 22 control neurons (1) and 23 neurons maintained in the presence of 100 pM IL-1 $\beta$ (2) for 5-6 days. Note increased points per bin for neurons maintained in the presence of the cytokine, indicating that more AP were generated in this population. Abscissa) Voltage, $\mathrm{mV}$ (voltage bins $10 \mathrm{mV}$ ); ordinate) number of digital points.

Р и с. 5. Використання "всеточкових" гістограм для ілюстрації підвищення збудливості середніх за розмірами нейронів дорсальнокорінцевих гангліїв. units and small IB4+ cells was increased, that of small IB4- neurons was unchanged, and that of large neurons was decreased. Data demonstrating increased excitability of medium cells from our original work [61] has been transformed as an "all-point histogram" in Fig. 5. The original digital points used to describe action potential discharges in response to a standard depolarizing current ramp were assigned to $10 \mathrm{mV}$ bins starting at $-20 \mathrm{mV}$ (A). Data points were collected from 19 control medium neurons and 25 medium neurons exposed to IL-1 $\beta$. The presence of more points in all $10 \mathrm{mV}$ bins positive with respect to $-20 \mathrm{mV}$ is indicative of increased action potential discharges in the continued presence of the cytokine. Although excitability of both medium and small IB4+ neurons was increased, dissimilar underlying ion mechanisms operated in the two cell types [62]. Thus, IL-1 $\beta$ significantly increased rates of hyperpolarization-activated cyclic nucleotidegated current $\left(I_{H}\right)$ activation in medium neurons and produced a leftward shift in the voltage dependence of activation of tetrodotoxin-sensitive sodium current (TTX-S $I_{\mathrm{Na}}$ ). There were also reductions in the densities of various potassium currents $\left(I_{\mathrm{K}}\right)$, such as $\mathrm{Ca}^{2+}$-dependent $\left(I_{\mathrm{K}, \mathrm{Ca}}\right)$ and A-type components. In small $\mathrm{IB}_{4}+\mathrm{DRG}$ neurons, IL-1 $\beta$ significantly slowed the rate of TTX-S $I_{\mathrm{Na}}$ inactivation and reduced the $I_{\mathrm{K}, \mathrm{Ca}}$ density without affecting A-type components of $I_{\mathrm{K}}$.

The general implication from these findings is that reduction of voltage-gated sodium channel currents, enhancing of increasing $\mathrm{K}^{+}$currents, or reduction of $I_{\mathrm{H}}$ may represent prospective therapeutic approaches to neuropathic pain. Decreases in $\mathrm{K}^{+}$channel currents can be attenuated by the use of $\mathrm{K}^{+}$channel activators [63]. These include retigabine [64, 65] for Kv7.2 and 7.3 channels and SKA-31, DCEBIO, and CyPPA for intermediate- and small-conductance $I_{\mathrm{K}, \mathrm{Ca}}$ channels [66-68] . A wide variety of $\mathrm{Na}^{+}$channel blockers are available; some local anesthetics, newer compounds, such as ranolazine [69], the tarantula venom peptide ProTx-II [70], and certain sea anemone toxins [71], target $\mathrm{Na}_{\mathrm{v}}$ 1.7, a channel subtype strongly implicated in neuropathic pain $[72,73]$. Recently, the $I_{\mathrm{H}}$ channel blocker ivabradine was approved for the management of certain cardiac dysrhythmias and angina, but its ability to block $I_{\mathrm{H}}$ in DRG neurons remains to be demonstrated with respect to its ability to attenuate signs of neuropathic pain.

Targeting Synaptic Transmission in the Spinal Dorsal Horn. We have shown that CCI increases excitatory synaptic drive to putative excitatory neurons in the rat substantia gelatinosa whilst decreasing excitatory synaptic drive to putative inhibitory neurons $[74,75]$. Both effects are mediated, at least in part, by the release of BDNF from microglia [19, $76,77]$. Although the use of various types of glutamate antagonists has been suggested for use in neuropathic pain, results have been quite disappointing. This was perhaps because consideration was not given to the possibility that different glutamate (AMPA) receptor subtypes may exist on excitatory and inhibitory spinal cord neurons. In order to alleviate pain, it would seem desirable to selectively target AMPA receptors (AMPARs) on excitatory neurons. We, therefore, 
$A$

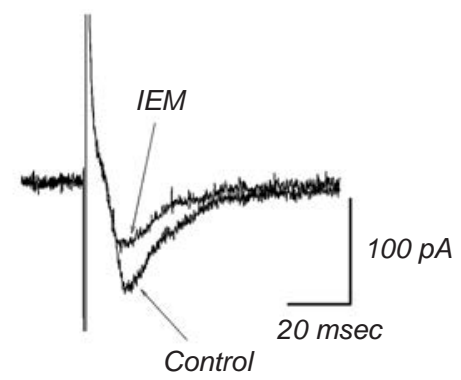

$B$

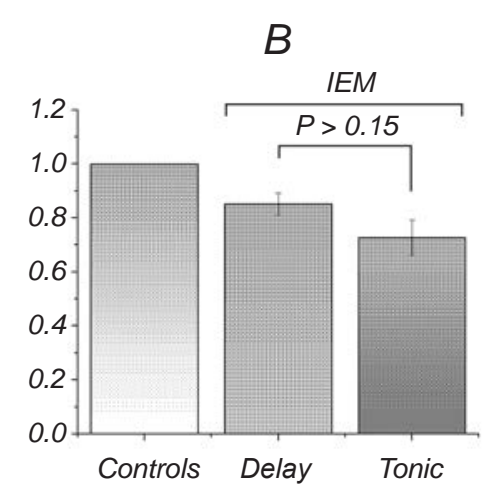

C Delay

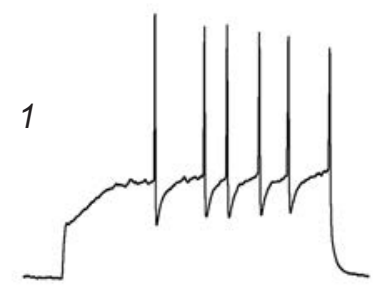

$D$

Tonic

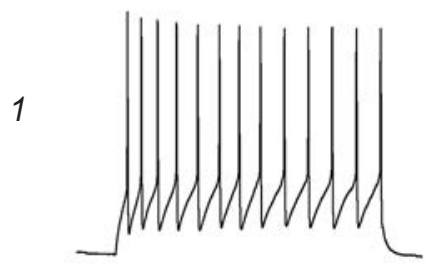

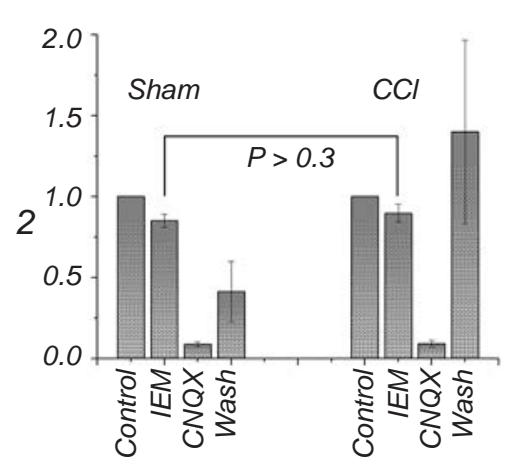

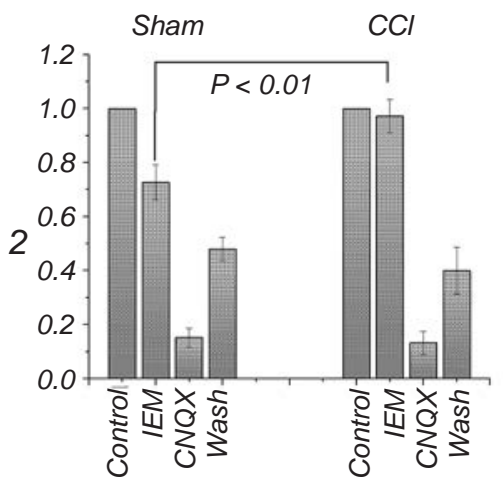

F i g. 6. Actions of IEM 1460 on excitatory synaptic transmission in substantia gelatinosa neurons. A) Superimposed recordings of evoked field EPSCs from the dorsal root entry zone before and after application of $50 \mathrm{mM}$ IEM 1460 (IEM). B) Diagram illustrating nearly similar effectiveness of IEM 1460 on tonic $(n=14)$ and delay $(n=18)$ neurons $(P>0.15)$. In C, 1) Characteristic firing pattern of a delay neuron to a depolarizing current command; 2) lack of the effect of CCI on the pharmacological properties of delay neurons. IEM 1460 (50 mM) produces nearly similar amounts of depression of evoked EPSCs in neurons $(n=14)$ from sham-operated (control) animals and in those from animals subjected to CCI $(n=10 ; P>0.3)$. In $\mathrm{D}, 1)$ Characteristic firing pattern of a tonic neuron in response to a depolarizing current stimulus; 2) CCI alters the pharmacological properties of tonic neurons. IEM $1460(50 \mathrm{mM})$ produces noticeable depression of evoked EPSCs in neurons from sham-operated animals $(n=18)$ but not in neurons from animals subjected to CCI $(n=14 ; P<0.01)$. Vertical scales in $\mathrm{C} 2$ and D2) Normalized amplitudes of field eEPSCs; control values are taken as 1.0.

Р и с. 6. Впливи IEM 1460 на збуджуючу синаптичну передачу в нейронах желатинозної субстанції.

used the selective polyamine blocker IEM1460 [78] to examine the distribution of $\mathrm{Ca}^{2+}$-permeable AMPA receptors (CP-AMPARs) on tonic-firing (putative inhibitory) and delay-firing (putative excitatory) neurons in the rat substantia gelatinosa [79]. Figure 6A illustrates superimposed evoked EPSCs (eEPSCs) in a substantia gelatinosa neuron by stimulation of the dorsal root entry zone. IEM $1460(50 \mu \mathrm{M})$ reduced the amplitude of the response by $35 \%$, and the response was almost completely eliminated by the subsequent addition of $5 \mu \mathrm{M}$ CNQX (data not shown). IEM reduced the eEPSC amplitude in delay neurons by $14.9 \pm$ $\pm 0.04 \%(n=14)$ and that in tonic neurons by $16.8 \pm$ $\pm 0.65 \%(n=18)$. Because the intensity of suppression in the two cell types is not significantly dissimilar $(P>$ $>0.15$; B), primary afferent synapses activate at least nearly similar populations of AMPARs on tonic and delay neurons. It has been suggested, however, that $\mathrm{Ca}^{2+}$-permeable AMPARs that lack GluA2 subunits play a major role in the etiology of inflammatory pain [80]. If a similar situation is true for neuropathic pain, this would suggest that drugs, such as IEM1460, would exert therapeutic benefit. In putative excitatory delay neurons, IEM reduces the eEPSC amplitude to a comparable extent in neurons from sham-operated and CCI animals. There is no obvious increase in IEM sensitivity (C). In contrast, there is a loss of IEM sensitivity in tonic neurons (D). It could be argued, therefore, that IEM1460 would continue to impede excitatory drive to excitatory neurons without that in CCI animals, while affecting that to inhibitory neurons. To the best of our knowledge, however, IEM has not yet been tested in vivo in chronic pain models. One issue that may impair the effectiveness of IEM is the 
possibility that not all tonic neurons are inhibitory [81].

Augmenting the Effectiveness of Currently Available Therapies. As was mentioned above, the gabapentinoid drugs gabapentin and pregabalin are first-line treatments for various forms of neuropathic pain in Western Europe and North America [4-7]. The effectiveness of these drugs is ascribed to the appearance of dose-dependant side effects, which preclude the use of higher and, potentially, more effective doses. It may be suggested that targeting gabapentinoids to nociceptive neurons and increasing their antiallodynic effectiveness might lessen the dizziness, drowiness, fatigue, and peripheral edema seen with these substances.

Gabapentinoids are transported into neurons via the L-neutral amino acid transporter system [82, 83]. Once inside, they bind with the $\beta 2 \delta$ accessory subunit of voltage-gated $\mathrm{Ca}^{2+}$ channels $[55-57,84]$. Since this subunit is involved in trafficking and insertion of $\mathrm{Ca}^{2+}$ channels into the cell membrane [85], prolonged exposure to gabapentinoids reduces the surface expression of $\mathrm{Ca}^{2+}$ channels. This is thought to impair voltage-gated $\mathrm{Ca}^{2+}$ influx into nerve terminals and to reduce neurotransmitter release. Such an action at primary afferent terminals is assumed to attenuate transfer of nociceptive information [55].

We suggest that TRPV1 channels may be used to load neurons with gabapentinoids. This idea was developed from observations with local anesthetics. Because local anesthetics must reach an intracellular site of action to exert their effect [86], quaternary (permanently positively charged) local anesthetics, such as QX $314^{+}$, are ineffective when applied extracellularly, as they fail to cross the plasma membrane. Yet when TRPV1 channels are opened by capsaicin, a potent anesthetic effect of QX $314^{+}$is observed both in vitro and in vivo $[87,88]$. This effect is ascribed to the permeation of open TRPV1 channels by QX $314^{+}$.

We have preliminary data to show that gabapentinoids can also enter neurons through open pores of the TRPV1 channels [89]. We synthesized a positively charged quaternary analog of gabapentin (Fig. 7A and B) [90] and used it to replace all cations in the extracellular fluid $\left(\mathrm{Na}^{+}, \mathrm{K}^{+}\right.$, and $\left.\mathrm{Ca}^{2+}\right)$. Whole-cell recordings
A

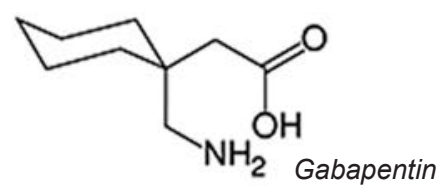

C

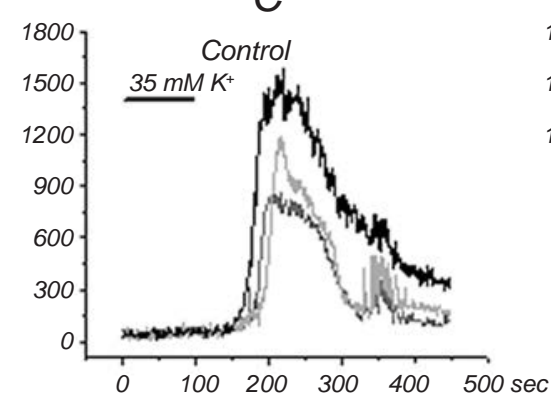

E

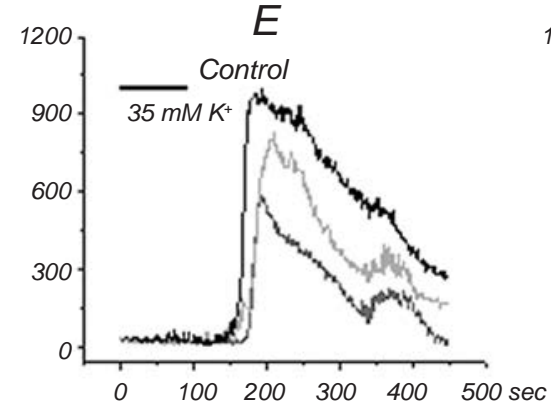

$B$

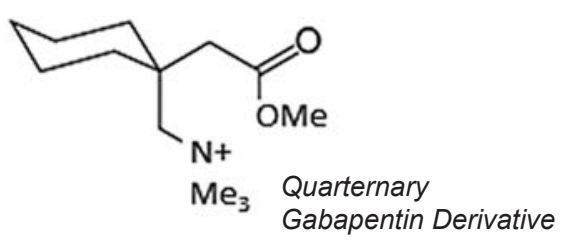

D

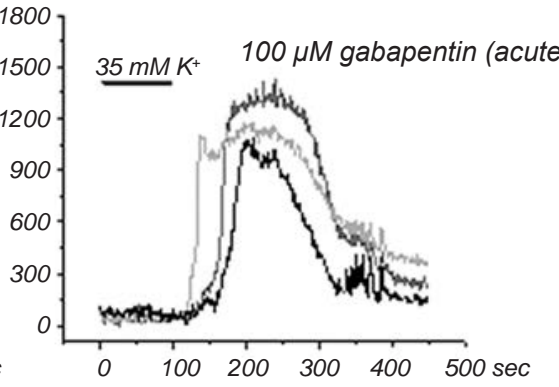

F

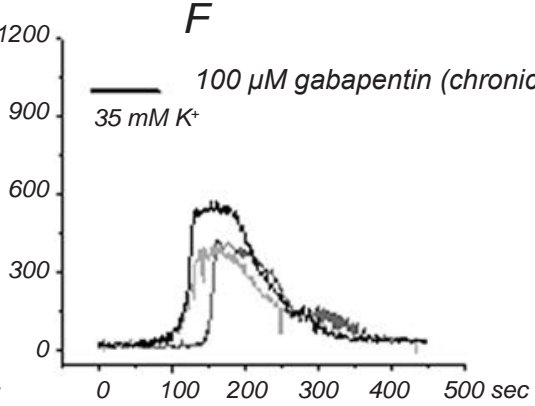

F i g. 7. Augmentation of the effectiveness of gabapentinoid by their permeation through TRPV1 channels. A) Structure of gabapentin. B) Structure of its quaternary analog [90]. C-F) Monitoring of the dorsal horn excitability by means of confocal $\mathrm{Ca}^{2+}$ imaging. Sample $35 \mathrm{mM} \mathrm{K} \mathrm{K}^{+}$-induced $\mathrm{Ca}^{2+}$ signals. While signals are unaffected by acute exposure to $100 \mathrm{mM}$ gabapentin (C and $\mathrm{D})$, a pronounced attenuation of $\mathrm{Ca}^{2+}$ signals is seen in a culture exposed to gabapentin for 5 days ( $\mathrm{E}$ and F). Abscissa) Time, sec; ordinate) arbitrary fluorescence units.

P и с. 7. Підвищення ефективності габапентиноїдів внаслідок їх проникнення через канали TRPV1. 
were made from small DRG neurons that express TRPV1 channels [91, 92]. When TRPV1 channels were opened by capsaicin, an inward current carried exclusively by the quarternary analog of gabapentin was noted. Since it was attached to the only available charge carrier, gabapentin must have entered neurons through TRPV1 channels. We then used organotypic cultures of the rat spinal cord and monitored their excitability by exposing them to high-potassium (35 $\mathrm{mM}$ ) challenge and recording changes in intracellular calcium by means of confocal imaging and fluo-4 AM [93]. After 5-day-long exposure to $100 \mu \mathrm{M}$ gabapentin, $\mathrm{Ca}^{2+}$ responses were significantly reduced, whereas acutely applied gabapentin was ineffective (C-F) [89]. Chronic exposure to gabapentin at a lower dose $(10 \mu \mathrm{M})$ failed to reduce the dorsal horn excitability when applied alone. However, when the cultures were transiently exposed to capsaicin (three 1-h-long applications) in the continued presence of this low (subeffective) concentration of gabapentin $(10 \mu \mathrm{M})$, a clear suppression of excitability, as monitored by evoked $\mathrm{Ca}^{2+}$ response, was seen (data not shown) [89]. Thus, capsaicin augments gabapentinoid effectiveness in vitro, but we have yet to demonstrate whether this combination is superior to gabapentinoids alone in relief of allodynia in vivo.

\section{DISCUSSION}

We have considered four possible targets for therapeutic intervention in neuropathic pain. These were blocking the action of inflammatory mediators at the site of injury, blocking consequences of mediator action at the site of injury, targeting synaptic transmission in the spinal dorsal horn, and augmenting the effectiveness of currently available therapies.

As was discussed above, it is unlikely that blocking the actions of peripheral inflammatory mediators will be effective, as the persistence of neuropathic pain results from chronic changes initiated by initial exposure to cytokines, such as IL-1 $\beta$. It is likely that these chronic downstream changes are already well-established in most clinical presentations of neuropathic pain.

Targeting ion channels in DRG neurons is, however, a more attractive influence. We were among the first laboratories to characterize the changes in ion channels and excitability of DRG neurons that were induced by peripheral nerve injury $[12,94-96]$. We demonstrated up-regulation of TTX-sensitive and
TTX-resistant $\mathrm{Na}^{+}$channels [96] and down-regulation of $\mathrm{Ca}^{2+}$ channels and various types of $\mathrm{K}^{+}$channels [95]; these findings have been replicated, refined, and greatly extended over the last 13 years [97-104]. Increases in the hyperpolarization-activated cation current $\left(I_{H}\right)[105,106]$, as well as increased expression of $\mathrm{Na}_{\mathrm{v}} 1.7$ sodium channels and $\mathrm{Ca}_{\mathrm{v}} 3.2 \mathrm{~T}$-type calcium channels have also been observed during various pain states [35, 107-109]. Although all such changes are capable of increasing the neuronal excitability, it is likely that dissimilar ion channels are affected in different types of neuropathic pain. For example, axotomy, chronic DRG compression, and chronic exposure to the pro-inflammatory cytokine IL-1 $\beta$ all increase the DRG neuron excitability $[12,14,37,40$, $42,43,61,110]$. Axotomy affects $\mathrm{Ca}^{2+}-, \mathrm{K}^{+}$, and TTXsensitive and resistant $\mathrm{Na}^{+}$channels $[95,96]$, whereas long-term IL-1 $\beta$ application and DRG compression affects H-currents (carried by HCN channels; Fig. 5) $[14,61,110,111]$. The T-type $\mathrm{Ca}^{2+}$ channel currents are increased by CCI and in diabetic neuropathy [35, 107] but not by axotomy [95].

This raises an important point. Because increases in the DRG excitability are brought about by different ion channel mechanisms in different nerve injury situations and/or disease states, it is likely that drugs that target injury-specific or disease-specific changes in ion channels will be effective in specific clinical situations. This may be the key to developing therapeutic approaches to some of the most intractable forms of neuropathic pain, such as that associated with HIV-AIDS neuropathy. The appropriate ion channels have to be identified.

We have also considered interfering with synaptic transmission in the dorsal horn, and our in vitro results suggest that blockers of CP-AMPARs may be effective, but this has yet to be demonstrated in animal models of neuropathic pain in vivo.

Lastly, we considered the possibility of improving the gabapentinoid effectiveness by combining of these drugs with capsaicin. Since TRPV1 channels are often associated with nociceptive fibers and are up-regulated in certain pain states, TRPV1-facilitated entry of gabapentinoids will preferentially target pain transmission. Since topical capsaicin is already in use in pain management [112-116], its use in the combination may permit the use of lower doses of gabapentinoids, thereby reducing their tendency to promote drowsiness, peripheral edema, and dizziness. The combination may also allow one to use lower doses of capsaicin, which is currently applied topically 
in quite high concentrations [114-116]. Although this causes acute pain, which can last for days, it can relieve chronic pain for a month or more. The acute allogenic actions of capsaicin do, nevertheless, decrease the patient compliance. Thus, the possibility of using lower doses of topical capsaicin to augment the gabapentinoid effectiveness would also have potential therapeutic advantages.

Acknowedgments. This research was supported by grants from the Paralyzed Veterans of America, Pfizer Canada Neuropathic Pain Research Awards, and Canadian Institutes of Health Research (CIHR). P. Stemkowskii received studentship support and a Lionel McLoed award from the Alberta Heritage Foundation for Medical Research. We thank Dr. K. Ballanyi for use of confocal $\mathrm{Ca}^{2+}$ imaging facilities and Dr. V. Derkach for useful discussions and for suggesting the use of IEM1460.

\section{П. Л. Стемковський Н. Кумар ${ }^{1}$ П. А. Сміт}

\section{РОЗУМІННЯ МЕХАНІЗМІВ І ЛІКУВАННЯ НЕЙРОПАТИЧНОГО БОЛЮ}

\section{${ }^{1}$ Центр нейронаук Університету Альберта, Едмонтон (Канада).}

Р е 3 ю м е

Нейропатичний біль, який майже не підлягає адаптації до якого $€$ відсутньою, виникає внаслідок ушкоджень або захворювань нервової системи. Він, як правило, має хронічний характері частоє неусувним. Звичайні аналгетики, такі як опіоїди, в цих ситуаціях $є$ малопридатними, а габапентиноїди (прегабалін і габапентин) ефективні не в усіх випадках. При нейропатичному болю, що виникає в периферичних структурах, початкова запальна відповідь викликає вивільнення різноманітних медіаторів, включно 3 цитокінами та простагландинами, які змінюють експресію іонних каналів у первинних аферентних нейронах. Це призводить до ініціації ектотопічної активності в сенсорних нервах i вивільнення АТФ i другої групи медіаторів із терміналей первинних аферентів. Рівень активації спінальної мікроглії змінюється таким чином, що остання вивільнює третій набір медіаторів, зокрема мозковий нейротрофічний фактор (BDNF), у дорсальний piг спинного мозку. Через низку механізмів BDNF посилює збуджуючу синаптичну передачу та послаблює гальмівну. „Центральна сенситизація”, що розвивається в результаті, зумовлює гіпералгезію, каузалгію та алодинію феномени, асоційовані $з$ нейропатичним болем. Наявність змін в іонних каналах сенсорних нервових структур i модуляції збуджуючої передачі в дорсальному розі визначає високу необхідність вишукувань нових підходів у лікуванні нейропатичного болю. Робиться припущення, що ефективність габапентиноїдів може бути збільшена за рахунок сполучення цих агентів 3 агоністом рецепторів TRPV1 капсаїцином.

\section{REFERENCES}

1. R.-D. Treede, T. S. Jensen, J. N. Campbell, et al., "Neuropathic pain: Redefinition and a grading system for clinical and research purposes," Neurology, 70, No. 18, 1630-1635 (2008).

2. M. Costigan, J. Scholz, and C. J. Woolf, "Neuropathic pain: a maladaptive response of the nervous system to damage," Annu. Rev. Neurosci., 32, 1-32 (2009).

3. R. S. Taylor, "Epidemiology of refractory neuropathic pain," Pain Practice, 6, No. 1, 22-26 (2006).

4. I. Gilron, C. P. Watson, C. M. Cahill, and D. E. Moulin, "Neuropathic pain: a practical guide for the clinician," Can. Med. Assn. J., 175, No. 3, 265-275 (2006).

5. D. E. Moulin, A. J. Clark, I. Gilron, et al., "Pharmacological management of chronic neuropathic pain - consensus statement and guidelines from the Canadian Pain Society," Pain Res. Manag., 12, No. 1, 13-21 (2007).

6. N. Attal, G. Cruccu, M. Haanpaa, et al., "EFNS guidelines on pharmacological treatment of neuropathic pain," Eur. J. Neurol., 13, No. 11, 1153-1169 (2006).

7. J. Sandkuhler, "Models and mechanisms of hyperalgesia and allodynia," Physiol. Rev., 89, No. 2, 707-758 (2009).

8. K. J. Kim, Y. W. Yoon, and J. M. Chung, "Comparison of three rodent models of neuropathic pain," Exp. Brain Res., 113, No. 2, 200-206 (1997).

9. T. Mosconi and L. Kruger, "Fixed-diameter polyethylene cuffs applied to the rat sciatic nerve induce a painful neuropathy: ultrastructural morphometric analysis of axonal alterations," Pain, 64, No. 1, 37-57 (1996).

10. C. Ma, Y. Shu, Z. Zheng, et al., "Similar electrophysiological changes in axotomized and neighboring intact dorsal root ganglion neurons," J. Neurophysiol., 89, No. 3, 1588-1602 (2003).

11. A. M. Binshtok, H. Wang, K. Zimmermann, et al., "Nociceptors are interleukin-1beta sensors," J. Neurosci., 28, No. 52, 1406214073 (2008).

12. F. A. Abdulla and P. A. Smith, "Axotomy and autotomyinduced changes in the excitability of rat dorsal root ganglion neurons," J. Neurophysiol., 85, No. 2, 630-643 (2001).

13. P. D. Wall and M. Devor, "Sensory afferent impulses result from dorsal root ganglia as well as from the periphery in normal and nerve-injured rats," Pain, 17, No. 4, 321-339 (1983).

14. P. L. Stemkowski and P. A. Smith, "Sensory neurons, ion channels, inflammation and the onset of neuropathic pain," Can. J. Neurol. Sci., 39, No. 4, 416-435 (2012).

15. S. Echeverry, X. Q. Shi, and J. Zhang, "Characterization of cell proliferation in rat spinal cord following peripheral nerve injury and the relationship with neuropathic pain," Pain, 135, Nos. 1/2, 37-47 (2008).

16. J. A. Coull, S. Beggs, D. Boudreau, et al., "BDNF from microglia causes the shift in neuronal anion gradient underlying neuropathic pain," Nature, 438, No. 7070, 1017-1021 (2005).

17. J. Scholz and C. J. Woolf, "The neuropathic pain triad: neurons, immune cells and glia," Nat. Neurosci., 10, No. 11, 1361-1368 (2007).

18. J. Zhang and Y. de Koninck, "Spatial and temporal relationship between monocyte chemoattractant protein-1 expression and spinal glial activation following peripheral nerve injury," $J$. Neurochem., 97, No. 3, 772-783 (2006).

19. V. B. Lu, K. Ballanyi, W. F. Colmers, and P. A. Smith, "Neuron type-specific effects of brain-derived neurotrophic factor in rat superficial dorsal horn and their relevance to central sensitization," J. Physiol., 584, Part 2, 543-563 (2007). 
20. C. J. Woolf, "Evidence for a central component of post-injury pain hypersensitivity," Nature, 306, No. 5944, 686-688 (1983).

21. C. J. Woolf and R. J. Mannion, "Neuropathic pain: aetiology, symptoms, mechanisms, and management," Lancet, 353, No. 9168, 1959-1964 (1999).

22. K. A. Moore, T. Kohno, L. A. Karchewski, et al., "Partial peripheral nerve injury promotes a selective loss of GABAergic inhibition in the superficial dorsal horn of the spinal cord," $J$. Neurosci., 22, No. 15, 6724-6731 (2002).

23. A. Dalal, M. Tata, G. Allégre, et al., "Spontaneous activity of rat dorsal horn cells in spinal segments of sciatic projection following transection of sciatic nerve or of corresponding dorsal roots," Neuroscience, 94, No. 1, 217-228 (1999).

24. C. A. von Hehn, R. Baron, and C. J. Woolf, "Deconstructing the neuropathic pain phenotype to reveal neural mechanisms," Neuron, 73, No. 4, 638-652 (2012).

25. F. Marchand, M. Perretti, and S. B. McMahon, "Role of the immune system in chronic pain," Nat. Rev. Neurosci., 6, No. 7, 521-532 (2005).

26. S. Sun, H. Cao, M. Han, et al., "New evidence for the involvement of spinal fractalkine receptor in pain facilitation and spinal glial activation in rat model of monoarthritis," Pain, 129, Nos. 1/2, 64-75 (2007).

27. M. Zhuo, "Cortical excitation and chronic pain," Trends Neurosci., 31, No. 4, 199-207 (2008).

28. S. M. Gustin, C. C. Peck, L. B. Cheney, et al., "Pain and plasticity: Is chronic pain always associated with somatosensory cortex activity and reorganization?" J. Neurosci., 32, No. 43, 14874-14884 (2012).

29. J. D. Carlson, J. J. Maire, M. E. Martenson, and M. M. Heinricher, "Sensitization of pain-modulating neurons in the rostral ventromedial medulla after peripheral nerve injury," $J$. Neurosci., 27, No. 48, 13222-13231 (2007).

30. L. P. Vera-Portocarrero, E. T. Zhang, M. H. Ossipov, et al., "Descending facilitation from the rostral ventromedial medulla maintains nerve injury-induced central sensitization," Neuroscience, 140, No. 4, 1311-1320 (2006).

31. E. M. Pogatzki, M. O. Urban, T. J. Brennan, and G. F. Gebhart, "Role of the rostral medial medulla in the development of primary and secondary hyperalgesia after incision in the rat," Anesthesiology, 96, No. 5, 1153-1160 (2002).

32. M. H. Ossipov, J. Lai, T. P. Malan, Jr., and F. Porreca, "Spinal and supraspinal mechanisms of neuropathic pain," Ann. New York Acad. Sci., 909, 12-24 (2000).

33. M. J. Millan, "The induction of pain: An integrative review," Prog. Neurobiol., 57, No. 1, 1-164 (1999).

34. S. M. Carlton, J. Du, H. Y. Tan, et al., "Peripheral and central sensitization in remote spinal cord regions contribute to central neuropathic pain after spinal cord injury," Pain, 147, Nos. 1/3, 265-276 (2009).

35. M. M. Jagodic, S. Pathirathna, M. T. Nelson, et al., "Cellspecific alterations of T-type calcium current in painful diabetic neuropathy enhance excitability of sensory neurons," J. Neurosci., 27, No. 12, 3305-3316 (2007).

36. C. Power, L. Boisse, S. Rourke, and M. J. Gill, "NeuroAIDS: an evolving epidemic," Can. J. Neurol. Sci., 36, No. 3, 285295 (2009).

37. J. M. Zhang, D. F. Donnelly, X. J. Song, and R. H. LaMotte, "Axotomy increases the excitability of dorsal root ganglion cells with unmyelinated axons," J. Neurophysiol., 78, No. 5, 2790-2794 (1997).

38. M. Petersen, J. Zhang, J. M. Zhang, and R. H. LaMotte, "Abnormal spontaneous activity and responses to norepinephrine in dissociated dorsal root ganglion cells after chronic nerve constriction," Pain, 67, Nos. 2/3, 391-397 (1996).

39. C. Ma and R. H. LaMotte, "Multiple sites for generation of ectopic spontaneous activity in neurons of the chronically compressed dorsal root ganglion," J. Neurosci., 27, No. 51, 14059-14068 (2007).

40. C. N. Liu, P. Raber, S. Ziv-Sefer, and M. Devor, "Hyperexcitability in sensory neurons of rats selected for high versus low neuropathic pain phenotype," Neuroscience, 105, No. 1, 265-275 (2001).

41. M. Devor and Z. Seltzer, "Pathophysiology of damaged nerves in relation to chronic pain," in: Textbook of Pain, P. D. Wall and R. Melzack (eds.), Churchill Livingstone, Toronto (1999), pp. 129-164.

42. T. R. Cummins, S. D. Dib-Hajj, J. Black, and S. Waxman, "Altered excitability of large-diameter cutaneous afferents following nerve injury: consequences for chronic pain," in: Proceedings of the 9th World Congress on Pain, M. Devor, M. C. Rowbotham, and Z. Wiesenfeld-Hallin (eds.), Vol. 16, IASP Press, Seattle (2000), pp. 119-135.

43. C. N. Liu, P. D. Wall, E. Ben-Dor, et al., "Tactile allodynia in the absence of $\mathrm{C}$-fiber activation: altered firing properties of DRG neurons following spinal nerve injury," Pain, 85, No. 3, 503-521 (2000).

44. I. Sukhotinsky, E. Ben Dor, P. Raber, and M. Devor, "Key role of the dorsal root ganglion in neuropathic tactile hypersensibility," Eur. J. Pain, 8, No. 2, 135-143 (2004).

45. R. Amir, J. D. Kocsis, and M. Devor, "Multiple interacting sites of ectopic spike electrogenesis in primary sensory neurons," J. Neurosci., 25, No. 10, 2576-2585 (2005).

46. M. Devor, "Response of nerves to injury in relation to neuropathic pain," in: Wall and Melzack's Textbook of Pain, S. B. McMahon and M. Koltzenburg (eds.), Elsevier Churchill Livingstone, London, (2006), pp. 905-927

47. T. Ichiro, A. Tsugunobu, S. Kimiyasu, and K. Yasushi, "Allodynia and hyperalgesia induced by herpes simplex virus type-1 infection in mice," Pain, 86, Nos. 1/2, 95-101 (2000).

48. G. M. Pitcher and J. L. Henry, "Governing role of primary afferent drive in increased excitation of spinal nociceptive neurons in a model of sciatic neuropathy," Exp. Neurol., 214, No. 2, 219-228 (2008).

49. M. Devor, "Centralization, central sensitization and neuropathic pain. Focus on 'sciatic chronic constriction injury produces cell-type-specific changes in the electrophysiological properties of rat substantia gelatinosa neurons'," $J$. Neurophysiol., 96, No. 2, 522-523 (2006).

50. T. Kohno, R. R. Ji, N. Ito, et al., "Peripheral axonal injury results in reduced mu opioid receptor pre- and post-synaptic action in the spinal cord," Pain, 117, Nos. 1/2, 77-87 (2005).

51. F. A. Abdulla and P. A. Smith, "Axotomy reduces the effects of analgesic opioids yet increases the effects of nociceptin on dorsal root ganglion neurons," J. Neurosci., 18, No. 23, 9685 9694 (1998).

52. E. Milligan, V. Zapata, D. Schoeniger, et a1., "An initial investigation of spinal mechanisms underlying pain enhancement induced by fractalkine, a neuronally released chemokine," Eur. J. Neurosci., 22, No. 1, 2775-2782 (2005).

53. A. Ledeboer, E. M. Sloane, E. D. Milligan, et al., "Minocycline attenuates mechanical allodynia and proinflammatory cytokine expression in rat models of pain facilitation," Pain, 115, Nos. 1/2, 71-83 (2005).

54. S. Nadeau, M. Filali, J. Zhang, et al., "Functional recovery after 
peripheral nerve injury is dependent on the pro-inflammatory cytokines IL-1beta and TNF: implications for neuropathic pain," J. Neurosci., 31, No. 35, 12533-12542 (2011).

55. C. S. Bauer, M. Nieto-Rostro, W. Rahman, et al., "The increased trafficking of the calcium channel subunit alpha2delta-1 to presynaptic terminals in neuropathic pain is inhibited by the alpha2delta ligand pregabalin," J. Neurosci., 29, No. 3, 40764088 (2009).

56. F. Heblich, A. Tran Van Minh, J. Hendrich, et al., "Time course and specificity of the pharmacological disruption of the trafficking of voltage-gated calcium channels by gabapentin," Channels (Austin), 2, No. 1, 4-9 (2008).

57. J.Hendrich, A. T. Van Minh, F. Heblich, et al., "Pharmacological disruption of calcium channel trafficking by the $\mathrm{a}_{2} \mathrm{~d}$ ligand gabapentin," Proc. Natl. Acad. Sci. USA, 105, No. 9, 36283633 (2008).

58. J. Hendrich, C. S. Bauer, and A. C. Dolphin, "Chronic pregabalin inhibits synaptic transmission between rat dorsal root ganglion and dorsal horn neurons in culture," Channels (Austin), 6, No. 2, 124-132 (2012).

59. M. B. Hoppa, B. Lana, W. Margas, et al., " $\mathrm{a}_{2} \mathrm{~d}$ Expression sets presynaptic calcium channel abundance and release probability," Nature, 486, No. 7401, 122-125 (2012).

60. G. W. Zamponi, R. J. Lewis, S. M. Todorovic, et al., "Role of voltage-gated calcium channels in ascending pain pathways," Brain Res. Rev., 60, No. 1, 84-89 (2009).

61. P. L. Stemkowski and P. A. Smith, "Long-term IL-1beta exposure causes subpopulation-dependent alterations in rat dorsal root ganglion neuron excitability," J. Neurophysiol., 107, No. 6, 1586-1597 (2012).

62. P. L. Stemkowski and P. A. Smith, "Long-term exposure to $10^{-}$ ${ }^{18} \mathrm{M}$ interleukin-1в increases sensory neuron excitability," in: Proceedings of the 14th World Congress of Pain (IASP, Milan, Italy, 2012), Milan (2012), PH 237.

63. M. Takeda, Y. Tsuboi, J. Kitagawa, et al., "Potassium channels as a potential therapeutic target for trigeminal neuropathic and inflammatory pain," Mol. Pain, 7, article 5 (2011).

64. G. M. Passmore, A. A. Selyanko, M. Mistry, et al., "KCNQ/M currents in sensory neurons: significance for pain therapy," $J$. Neurosci., 23, No. 18, 7227-7236 (2003).

65. A. Dermody, T. Kamishima, J. Quayle, and L. Djouhri, "The KV7 Channel activator retigabine attenuates mechanical allodynia, but not heat hyperalgesia associated with painful diabetic neuropathy in rats," in: Proceedings of the 14th World Congress of Pain (IASP, Milan, Italy, 2012), Milan (2012), PH 103.

66. A. Sankaranarayanan, G. Raman, C. Busch, et al., "Naphtho[1,2-d]thiazol-2-ylamine (SKA-31), a new activator of $\mathrm{KCa} 2$ and $\mathrm{KCa} 3.1$ potassium channels, potentiates the endothelium-derived hyperpolarizing factor response and lowers blood pressure," Mol. Pharmacol., 75, No. 2, 281-295 (2009).

67. C. Hougaard, M. L. Jensen, T. J. Dale, et al., "Selective activation of the SK1 subtype of human small-conductance $\mathrm{Ca}^{2+}$-activated $\mathrm{K}^{+}$channels by 4-(2-methoxyphenylcarbamoyloxymethyl)piperidine-1-carboxylic acid tert-butyl ester (GW542573X) is dependent on serine 293 in the S5 segment," Mol. Pharmacol., 76, No. 3, 569-578 (2009).

68. P. Pedarzani, J. E. McCutcheon, G. Rogge, et al., "Specific enhancement of SK channel activity selectively potentiates the afterhyperpolarizing current I(AHP) and modulates the firing properties of hippocampal pyramidal neurons," J. Biol. Chem., 280, No. 50, 41404-41411 (2005).
69. H. J. Gould III, C. Garrett, R. R. Donahue, et al., "Ranolazine attenuates behavioral signs of neuropathic pain," Behav. Pharmacol., 20, No. 8, 755-758 (2009).

70. W. A.Schmalhofer, J. Calhoun, R. Burrows, et al., "ProTx-II, a selective inhibitor of NaV1.7 sodium channels, blocks action potential propagation in nociceptors," Mol. Pharmacol., 74, No. 5, 1476-1484 (2008).

71. P. Liu, S. Jo, and B. P. Bean, "Modulation of neuronal sodium channels by the sea anemone peptide BDS-I," J. Neurophysiol., 107, No. 11, 3155-3167 (2012).

72. S. D. Shields, X. Cheng, N. Uçeyler, et al., "Sodium channel $\mathrm{Na}(\mathrm{v}) 1.7$ is essential for lowering heat pain threshold after burn injury," J. Neurosci., 32, No. 32, 10819-10832 (2012).

73. S. D. Dib-Hajj, A. M. Rush, T. R. Cummins, et al., "Gainof-function mutation in Nav1.7 in familial erythromelalgia induces bursting of sensory neurons," Brain, 128, Part 8, 1847-1854 (2005).

74. Y. Chen, S. Balasubramanyan, A. Y. Lai, et al., "Effects of sciatic nerve axotomy on excitatory synaptic transmission in rat substantia gelatinosa," J. Neurophysiol., 102, No. 6, 32033215 (2009).

75. S. Balasubramanyan, P. L. Stemkowski, M. J. Stebbing, and P. A. Smith, "Sciatic chronic constriction injury produces celltype specific changes in the electrophysiological properties of rat substantia gelatinosa neurons," J. Neurophysiol., 96, No. 2, 579-590 (2006).

76. V. B. Lu, J. E. Biggs, M. J. Stebbing, et al., "BDNF drives the changes in excitatory synaptic transmission in the rat superficial dorsal horn that follow sciatic nerve injury," $J$. Physiol., 587, Part 5, 1013-1032 (2009).

77. J. E. Biggs, V. B. Lu, M. J. Stebbing, et al., "Is BDNF sufficient for information transfer between microglia and dorsal horn neurons during the onset of central sensitization?" Mol. Pain, 6, article 44 (2010).

78. L. G. Magazanik, S. L. Buldakova, M. V. Samoilova, et al., "Block of open channels of recombinant AMPA receptors and native AMPA/kainate receptors by adamantane derivatives," $J$. Physiol., 505, Part 3, 655-663 (1997).

79. T. Yasaka, S. Y. Tiong, D. I. Hughes, et al., "Populations of inhibitory and excitatory interneurons in lamina II of the adult rat spinal dorsal horn revealed by a combined electrophysiological and anatomical approach," Pain, 151, No. 2, 475-488 (2010).

80. B. Hartmann, S. Ahmadi, P. A. Heppenstall, et al., "The AMPA receptor subunits GluR-A and GluR-B reciprocally modulate spinal synaptic plasticity and inflammatory pain," Neuron, 44, No. 4, 637-650 (2004).

81. S. F. Santos, S. Rebelo, V. A. Derkach, and B. V. Safronov, "Excitatory interneurons dominate sensory processing in the spinal substantia gelatinosa of rat," J. Physiol., 581, Part 1, 241-254 (2007).

82. T. Z. Su, E. Lunney, G. Campbell, and D. L. Oxender, "Transport of gabapentin, a gamma-amino acid drug, by system 1 alpha-amino acid transporters: a comparative study in astrocytes, synaptosomes, and CHO cells," J. Neurochem., 64, No. 5, 2125-2131 (1995).

83. M. Palacin, R. Estevez, J. Bertran, and A. Zorzano, "Molecular biology of mammalian plasma membrane amino acid transporters," Physiol. Rev., 78, No. 4, 969-1054 (1998).

84. M. J. Field, P. J. Cox, E. Stott, et al., "Identification of the alpha2-delta-1 subunit of voltage-dependent calcium channels as a molecular target for pain mediating the analgesic actions 
of pregabalin," Proc. Natl. Acad. Sci. USA, 103, No. 46, 17537-17542 (2006).

85. A. Davies, J. Hendrich, A. T. Van Minh, et al., "Functional biology of the alpha(2)delta subunits of voltage-gated calcium channels," Trends Pharmacol. Sci., 28, No. 5, 220-228 (2007).

86. B. Hille, "Local anesthetics: hydrophilic and hydrophobic pathways for the drug-receptor reaction," J. Gen. Physiol., 69, No. 4, 497-515 (1977).

87. A. M. Binshtok, B. P. Bean, and C. J. Woolf, "Inhibition of nociceptors by TRPV1-mediated entry of impermeant sodium channel blockers," Nature, 449, No. 7162, 607-610 (2007).

88. A. M. Binshtok, P. Gerner, S. B. Oh, et al., "Coapplication of lidocaine and the permanently charged sodium channel blocker QX-314 produces a long-lasting nociceptive blockade in rodents," Anesthesiology, 111, No. 1, 127-137 (2009).

89. J. E. Biggs, P. Stemkowski, K. Ballanyi, and P. A. Smith, "'Spicing Up' the gabapentinoids," in: Proceedings of the 13th World Congress of Pain (Montreal 2010), PQ (2010), PH 148.

90. M. A. Chowdhury, P. A. Smith, and E. E. Knaus, "An efficient methodology for the synthesis of 1-trimethylammoniummethyl) cyclohexaneacetic acid iodide: A trimethylammonium iodide salt of gabapentin," Organic Preparations and Procedures International (OPPI): New J. Organ. Synthes., 42, No. 1, 103106 (2010).

91. M. J. Caterina, M. A. Schumacher, M. Tominaga, et al., "The capsaicin receptor: a heat-activated ion channel in the pain pathway," Nature, 389, No. 6653, 816-824 (1997).

92. M. J. Caterina and D. Julius, "The vanilloid receptor: a molecular gateway to the pain pathway," Annu. Rev. Neurosci., 24, 487-517 (2001).

93. J. E. Biggs, V. B. Lu, H. Kim, et al., "Defined medium organotypic cultures of spinal cord put 'pain in a dish'," in: Isolated Central Nervous System Circuits, Neuromethods, Vol. 73, Chap. 14, K. Ballanyi (ed.), Humana Press, Springer, New York (2012), pp. 405-436.

94. S. Gurtu and P. A. Smith, "Electrophysiological characteristics of hamster dorsal root ganglion cells and their response to axotomy," J. Neurophysiol., 59, No. 2, 408-423 (1988).

95. F. A. Abdulla and P. A. Smith, "Axotomy- and autotomyinduced changes in $\mathrm{Ca}^{2+}$ and $\mathrm{K}^{+}$channel currents of rat dorsal root ganglion neurons," J. Neurophysiol., 85, No. 2, 644-658 (2001).

96. F. A. Abdulla and P. A. Smith, "Changes in $\mathrm{Na}^{+}$channel currents of rat dorsal root ganglion neurons following axotomy and axotomy-induced autotomy," J. Neurophysiol., 88, No. 5, 2518-2529 (2002).

97. A. A. Sleeper, T. R. Cummins, S. D. Dib-Hajj, et al., "Changes in expression of two tetrodotoxin-resistant sodium channels and their currents in dorsal root ganglion neurons after sciatic nerve injury but not rhizotomy," J. Neurosci., 20, No. 19, 7279-7289 (2000).

98. B. Everill, T. R. Cummins, S. G. Waxman, and J. D. Kocsis, "Sodium currents of large (A $\beta$-type) adult cutaneous afferent dorsal root ganglion neurons display rapid recovery from inactivation before and after axotomy," Neuroscience, 106, No. 1, 161-169 (2001).

99. J. A. Black, S. Liu, M. Tanaka, et al., "Changes in the expression of tetrodotoxin-sensitive sodium channels within dorsal root ganglia neurons in inflammatory pain," Pain, 108, No. 3, 237-247 (2004).

100. M. Estacion, S. D. Dib-Hajj, P. J. Benke, et al., "NaV1.7 gain-of-function mutations as a continuum: A1632E displays physiological changes associated with erythromelalgia and paroxysmal extreme pain disorder mutations and produces symptoms of both disorders," J. Neurosci., 28, No. 43, 1107911088 (2008).

101. M. L. Baccei and J. D. Kocsis, "Voltage-gated calcium currents in axotomized adult rat cutaneous afferent neurons," J. Neurophysiol., 83, No. 4, 2227-2238 (2000).

102. M. S. Gold, D. Weinreich, C. S. Kim, et al., "Redistribution of NaV1.8 in uninjured axons enables neuropathic pain," $J$. Neurosci., 23, No. 1, 158-166 (2003).

103. J. Lai, F. Porreca, J. C. Hunter, and M. S. Gold, "Voltage-gated sodium channels and hyperalgesia," Annu. Rev. Pharmacol. Toxicol., 44, 371-397 (2004).

104. Q. H. Hogan, J. B. McCallum, C. Sarantopoulos, et al., "Painful neuropathy decreases membrane calcium current in mammalian primary afferent neurons," Pain, 86, Nos. 1/2, 43-53 (2000).

105. Q. H. Hogan and M. Poroli, "Hyperpolarization-activated current $\left(I_{\mathrm{h}}\right)$ contributes to excitability of primary sensory neurons in rats," Brain Res., 1207, 102-110 (2008).

106. H. Yao, D. F. Donnelly, C. Ma, and R. H. LaMotte, "Upregulation of the hyperpolarization-activated cation current after chronic compression of the dorsal root ganglion," J. Neurosci., 23, No. 6, 2069-2074 (2003).

107. M. M. Jagodic, S. Pathirathna, P. M. Joksovic, et al., "Upregulation of the T-type calcium current in small rat sensory neurons after chronic constrictive injury of the sciatic nerve," J. Neurophysiol., 99, No. 6, 3151-3156 (2008).

108. E. C. Emery, G. T. Young, and P. A. McNaughton, "HCN2 ion channels: an emerging role as the pacemakers of pain," Trends Pharmacol. Sci., 33, No. 8, 456-463 (2012).

109. E. C. Emery, G. T. Young, E. M. Berrocoso, et al., "HCN2 ion channels play a central role in inflammatory and neuropathic pain," Science, 333, No. 6048, 1462-1466 (2011).

110. P. L. Stemkowski and P. A. Smith, "Increases in sensory neuron excitability after interleukin 1-beta is driven by $\mathrm{H}$-current and calcium currents but not sodium currents," in: Proceedings of the 3rd CAN-ACN Meeting, Vancouver (2009).

111. Z. Y. Tan, D. F. Donnelly, and R. H. LaMotte, "Effects of a chronic compression of the dorsal root ganglion on voltagegated $\mathrm{Na}^{+}$and $\mathrm{K}^{+}$currents in cutaneous afferent neurons," $J$. Neurophysiol., 95, No. 2, 1115-1123 (2006).

112. A. B. O'Connor and R. H. Dworkin, "Treatment of neuropathic pain: an overview of recent guidelines," Am. J. Med., 122, Suppl. 10, S22-S32 (2009).

113. R. H. Dworkin, A. B. O'Connor, J. Audette, et al., "Recommendations for the pharmacological management of neuropathic pain: an overview and literature update," Mayo Clin. Proc., 85, Suppl. 3, S3-S14 (2010).

114. D. M. Simpson, S. Brown, and J. Tobias, "Controlled trial of high-concentration capsaicin patch for treatment of painful HIV neuropathy," Neurology, 70, No. 24, 2305-2313 (2008).

115. D. M. Simpson, L. Estanislao, S. J. Brown, and J. Sampson, "An open-label pilot study of high-concentration capsaicin patch in painful HIV neuropathy," J. Pain Symptom Management, 35, No. 3, 299-306 (2008).

116. D. M. Simpson, S. Gazda, S. Brown, et al., "Long-term safety of NGX-4010, a high-concentration capsaicin patch, in patients with peripheral neuropathic pain," J. Pain Symptom Management, 39, No. 6, 1053-1064 (2010). 